\title{
INCREMENT DIFFERENCES OF SILVER BIRCH BETULA PENDULA ROTH AND DOWNY BIRCH B. PUBESCENS EHRH. GROWING IN DRAINED SOILS IN SOUTH LATVIA
}

\begin{abstract}
Dagnija BĒRZIN̦A, Forest Faculty, Latvia University of Agriculture, Latvia, Jelgava, Akademijas Str. 11, LV-3001, berzina.dagnija@gmail.com (corresponding author)

Olga MIEZĪTE, Forest Faculty, Latvia University of Agriculture, Latvia, Jelgava, Akademijas Str. 11, LV-3001, olga.miezite@1lu.lv Jeḷena RŪBA, Forest Faculty, Latvia University of Agriculture, Latvia, Jelgava, Akademijas Str. 11, LV-3001, jelena.ruba@1lu.lv Linards SISENIS, Forest Faculty, Latvia University of Agriculture, Latvia, Jelgava, Akademijas Str. 11, LV-3001, linards.sisenis@1lu.lv

Imants LIEPA, Forest Faculty, Latvia University of Agriculture, Latvia, Jelgava, Akademijas Str. 11, LV-3001, imants.liepa@1lu.lv

According to State Forest Service information for the year 2016 birch occupied 30\% of whole forest area (3.38 million ha). Although between these two species have dendrological differences, however in forest inventory it is not taken into account. There is also a variety of wood properties which are not respected in the timber market. The aim of this research study is to analyze growth differences between both birch growing in the same conditions. For collecting of empirical data 2 sample plots were created. Selected stands have been regenerated naturally and 2 times repeatedly drained. The forest stand investigated is 65 years old mixed stand dominated by birch which makes up $90 \%$ of total growing stock. In each plot for all the trees have been measured diameter, height and using Pressler borer have been taken core samples. The widths of tree rings have been measured using Lin TAB system microscope and computer software T-Tools Pro. Analyzing the dynamics of diameter and height growth in both sample plots it has been observed that silver birch shows higher values than downy birch $(\mathrm{p}<0.05)$. In the last 30 years both birch species show systematic reduction of the annual increment. Decrease of height growth for both birch species in Vacciniosa mel. - 0.26-0.66 m. Decrease of B.pendula height growth in Vacciniosa turf. mel. - 0.39-0.70 m while B.pubescens - 0.39-0.80 m. Decrease of the stem diameter at breast height (DBH) of B.pendula - 2.7-7.5 mm while DBH of B.pubescens - 2.7-5.9 mm.
\end{abstract}

Keywords: downy birch, growth, silver birch.

\section{INTRODUCTION}

In European forests there are two commercially significant birch species: silver birch (B.pendula) and downy birch (B.pubescens). Both species have a wide natural distribution in the Eurasian continent, from the Atlantic ocean to East Siberia. Although birch is populated in nearly all places within Europe, most often birch resources are located in temperate and boreal forests of Northern Europe. The percentage of birch stands in the Baltic and Nordic countries ranges from 11 to 28 percent (Hynynen et al., 2009).

In general, silver and downy birch are similar to each other, i.e., both have white trunks and both of them can grow up to 20 to $30 \mathrm{~m}$. Nevertheless, differences regarding the morphology of leaves, branches, bark, and seeds as well as cellar size and tree anatomy occur (Jonsell, 2000). In some cases, it is complicated to make a distinction between silver and downy birch according to their morphological features excludingly. Sweden has developed a species identification method based on the chemical features of bark (Lundgren et al., 1995).

Currently, birch (both B. pendula and B. pubescens) is considered to be commercially most significant broadleaved tree in Northern and Eastern Europe (Hynynen et al., 2009). Birch (Betula spp.) is one of the most economically significant tree species in Latvia as well with areas of birch stands growing steadily. According to State Forest Service in 2016 birch stands accounted for 30 percent of the total area of forest lands (3.32 mill. ha).

Within the territory of Latvia, birch stands are distributed unevenly, with a larger density in the eastern part of the country (Zālītis, 2008). The greatest percentage of birch stands can be observed in private forests, what can be explained by the fact that after a clear cut, birch, being a pioneer species, occupy the area at a rapid pace, due to its high seed yield and rapid increase in young age, which makes it possible to compete with other tree species. Besides, birch trunk wood is a significant timber product in forestry (Liepiņš et al., 2013).

Copyright (C) 2017 The Authors. Published by Aleksandras Stulginskis University. This is an open-access article distributed under the terms of the Creative Commons Attribution License (CC-BY 4.0), which permits unrestricted use, distribution, and reproduction in any medium, provided the original author and source are credited. 
In comparison to other tree species, birch has a number of advantages: its ability of natural regeneration is very successful, therefore, forest owners do not have to take care of the purchase of planting material as well as the property of birch is important - transpiration of soil water (Liepa et al., 2016).

Four birch species can be observed in Latvian forests, but economically significant are only two: warty or silver birch (B.pendula) and downy or moor birch (B.pubescens) (Zviedre, Mangalis, 2003), which are not separated from each other in forest inventory, although their forestrial and morphological features, productivity, the number of chromosomes and wood quality also differ (Liepiņš, 2011; Liepiņš, 2013).

Silver birch is susceptible to rapid groundwater fluctuations, and in order to maitain a successful growing process, it requires for loose soils, rich in nutrients, with an evenly distributed level of humidity throughout a year (Mauriņš, Zvirgzds, 2009). The most suitable soils for productive growing stands are loamysoil and sandy loam. In such soil, birch can reach a site index of I - Ia at the age of 45 - 65 years (Zviedre, Mangalis, 2003).

Downy birch is not as demanding as silver birch and is able to grow in various conditions, such as dense soils (Hynynen et al., 2009), marshes, on the banks of water bodies and in valleys. The largest increments were observed under humid conditions, in sandy loam, loose and claley sand soil (Mauriňš, Zvirgzds, 2009). Growing on wet organic soils, downy birch is more competitive than silver birch, but the silver birch reaches a larger height and diameter at breast height growing in mineral soils or in abandoned agricultural lands.

Silver birch occurs in pure and mixed stands along with moor birch, Norway spruce and other tree species (Mauriņš, Zvirgzds, 2009). The best inventory results are expected for both birch species growing in Myrtillosa mel. and Myrtillosa turf. Mel., as well as Vacciniosa mel. and Vacciniosa turf. mel. (Zviedre, 1998). In pure and mixed stands silver and downy birch have different growing potential, therefore each of these birch species requires for an individual management program (Lungren et al., 1995).

Usually the final product of a naturally regenerated birch stand is pulpwood. In pure stand of silver birch high grade saw logs or veneer logs can be obtained but using different forestry techniques must be achieved to grow large diameter, straight trunks without any damage. If appropriate forestrial operations are being executed in the mixed stands, silver birch trunks can reach the size of high-value saw logs (Hynynen et al., 2009). In other countries, such as Finland, downy birch is mainly being grown for pulpwood as well as for acquistion of power-generating wood (Niemisto, 2013).

The objective of this study is to analyze increment differences between two birch species in the same forest type (growth conditions).

\section{RESEARCH METHODS}

For empirical data collection in birch ecosystems in South Latvia, Zemgale plain 2 plots (PL) were installed. The first plot (PL) edge lengths were 40x45m $\left(0.18 \mathrm{~m}^{2}\right)$, while the second - 40x40 m $\left(0.16 \mathrm{~m}^{2}\right)$. Selected stands were naturally formed and had been drained, twice. The mixed stands were 65 years old with prevailing species as birch (silver and downy birch), which comprises $90 \%$ of the total growing stock and Scots pine (Pinus sylvestris L.). In first PL the forest type was Vaccinosa mel. (Am) while in the second - Myrtillosa mel. (As).

Every tree in the plot was numbered with the labeling paint. According to morphological features (bark) species of each birch was identified. All tree diameters at $1.3 \mathrm{~m}$ above root collar (accuracy $1 \mathrm{~mm}$ ) were measured using Mantax Precision mechanical caliper, height (accuracy $0.1 \mathrm{~m}$ ) was detected using Vertex electronic height meter, as well as drills were made using Presler increment borer. The widths of tree rings have been measured by using Lin TAB system microscope and the computer software T-Tools Pro. As the tree rings of birch wood are not distinct, the possible margin of error was assumed to be $\pm 0.01 \mathrm{~mm}$. The annual increment of stock diameter at $1.3 \mathrm{~m}$ above root collar $\left(Z_{D}\right)$, describing both wood and bark increment, the annual increment of stand height $\left(Z_{H}\right)$ and the actual annual increment of wood stock of the stand $\left(Z_{M}\right)$ were calculated by formula 1 to 3 (Liepa, 1996):

$$
Z_{D}=2 \cdot i \cdot u
$$

where $Z_{D}$ - annual increment of stand diameter at $1,3 \mathrm{~m}$ above root collar, $\mathrm{mm}$;

$i$ - average width of tree rings at $1.3 \mathrm{~m}$ above root collar, $\mathrm{mm}$;

$u$ - empirical ratio (see table 2.4.2 below).

Annual increment of stand height $\left(Z_{H}\right)$ was calculated:

$$
Z_{H}=\frac{2 \cdot i \cdot H(\alpha \cdot D+b)}{c \cdot D+100},
$$

where $Z_{H}$ - annual increment of stand height, m;

$H$ - average height of stand, m;

$D$ - stand diameter at $1.3 \mathrm{~m}$ above root collar with bark, $\mathrm{cm}$;

$\alpha, b, c$-empirical ratios (Table 1).

Table 1.Values of empirical ratios.

\begin{tabular}{|l|c|c|c|c|}
\hline \multirow{2}{*}{ Species } & \multicolumn{3}{|c|}{ Height increments } & \\
\cline { 2 - 5 } & $a$ & $b$ & -35.710 & $u$ \\
\hline Birch & -0.0728 & -1.510 & 27.105 & 1.095 \\
\hline Pine & -0.0642 & 6.356 & 1.103 \\
\hline
\end{tabular}

Source: Liepa, 1996. 
The actual reduced annual increment of wood stock of the stand was calculated using formula (3):

$$
Z_{M}=12732.4 \cdot \psi \cdot H^{\alpha} \cdot D^{(\beta \cdot \lg H+\varphi-2)} \cdot\left(\frac{Z_{H}(\alpha+\beta \cdot \lg D)}{H}+\frac{Z_{D}(\varphi+\beta \cdot \lg H)}{10 D}\right),
$$

where $Z_{M}$ - actual reduced annual wood stock increment, $\mathrm{m}^{3} \mathrm{~m}^{-2}$. Using this formula, it must meet the following requirements: $1.5 \leq H \leq 40.0 \mathrm{~m}$ and $1.5 \leq D \leq 60.0 \mathrm{~cm}$ (Liepa, 1996).

The annual increment of stand capacity was calculated by formula (4):

$$
Z_{V}=G \cdot Z_{M}
$$

where $Z_{V}$ - annual increment of stand capacity, $\mathrm{m}^{3} \mathrm{ha}^{-1}$.

In the first PL 32 annual ring cores from silver birch and 18 tree ring cores from downy birch were gathered. In the second PL 27 silver birch and 19 downy birch cores were drilled. In the fist PL out of 32 cores of silver birch wood acquired, 28 initially were measured while downy birch was measured by one less than the drilled 18 cores but in the second PL 25 out of 27 cores of silver birch wood were measured and 15 out of 19 cores of downy birch. In total, 11 samples of birch wood cores were rejected and main reasons were rot-caused stains, inner branches and invisible growth borderlines.

\section{RESULTS}

Tree increment is described as the fytomass acquired year-by-year, which mainly depends mainly on climatic and anthropogenic factors. Birch being a fast-growing and sun-loving species and in comparison to conifer its increments in young age are significantly larger (Liepa, 2003). An increment within a one-year-period is characterised by annual increment. This increment is the dynamic indicator of stand inventory expressed in terms of year, therefore, it is advisable to use analyzing the effectiveness of forest management measures (Liepa, 2011).

In this study the increments of diameter, height and wood stock of B.pendula and B.pubescens during the last 30 years $(1986-2015)$ were analyzed. The annual increment of birch was viewed from the age of 35 years.

\section{Annual increment of height}

As the abscissa axis the period of study was postponed (in years), but on the as ordinate axis - the annual increment of average height $\left(Z_{H}\right),(\mathrm{m})$ which is one of the factors influencing indicators of wood stock increment (Fig. 1). In the I PL as well as in the II systematic decrease of the annual increment of height for both birch stands was observed. However, shorter and longer periods have been observed when the height increments of downy birch even slightly exceeded the increments of silver birch, as well as periods, when height increments of both species were identical. For example, in the II PL from 2004 to 2009 the significant local maximums and minimums of increment of silver birch were identified. It was found that during the same period the growth of downy birch has increased from $0.36 \mathrm{~m}$ to $0.45 \mathrm{~m}$, and then there has been a rapid decline. The fact that both birch species had a tendency to demonstrate larger of smaller downturn in the plots, can be explained by an observation that the peak point of height increment had been reached already and was followed by its decrease. Another reasonable explanation might be a more intense rainfall period. As is known, downy birch prefers to grow in locations with a higher ground-water level but the idea of atmospheric precipitation, as the main contributing factor to the situation described above, is just an assumption that has not been scientifically verified.

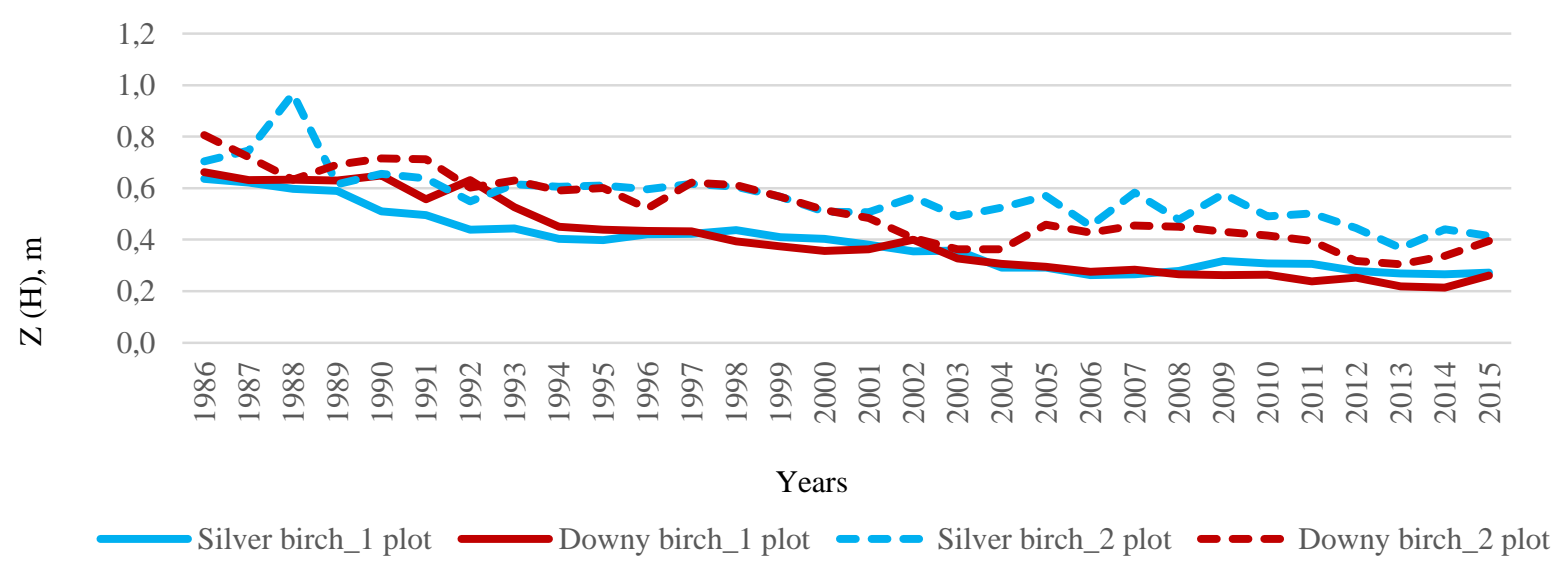

Figure 1. Comparison of the dynamics of annual increment of the average height of silver and downy birch.

\section{Annual increment of diameters}

Analyzing in both plots (Vaccinosa mel. and Myrtillosa mel.), silver birch showes larger values of diameters than downy birch. With increasing age of forest stands a gradual annual decrease in increment of height and diameter was 
observed. It can been explained by an observation that the birches have already surpassed the peak of growth, and at the age of 35 it has been experiencing a downturn.

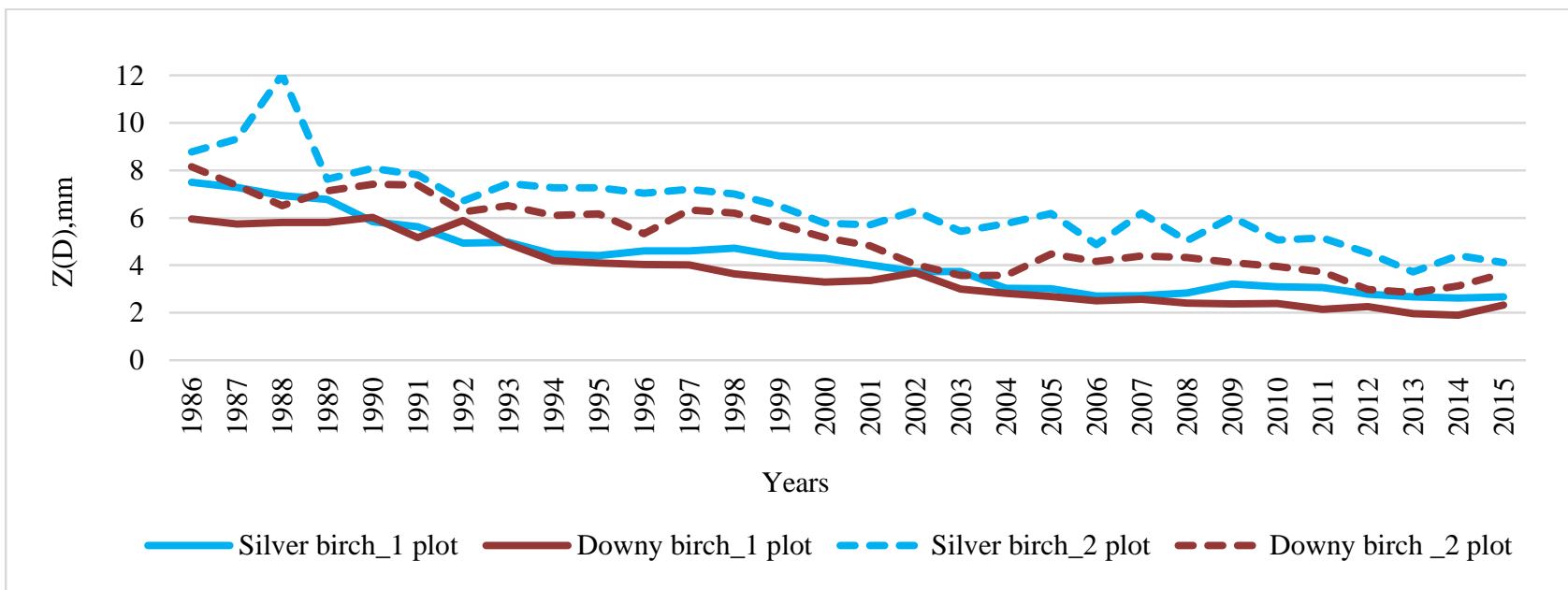

Figure 2. Comparison of the dynamics of the annual increment of diameter of silver and downy birch.

In the second PL (Fig. 2) differences between both tree species were significantly larger. It can be explained by the influence of drainage, because, as mentioned earlier, near to the second PL (approximately $100 \mathrm{~m}$ ) a repeatedly renovated gully was located.

Particular local annual increment maximums and minimums of the annual increment of diameter for both birch species simultaneously were founded in 1988 and 1992, for downy birch - in 1996, 2004 and 2005, but for silver birch in 2013 and 2001 - 2010, which can be explained by rainfall variability. Although the information of meteorological indicators was being absent, on the basis of a fact that silver birch prefers to grow in soils of a normal level of humidity, while downy birch - in more humid soils, it is possible to assume that in 1988 there was ahigh air temperature and drought seasons. During this period, silver birch showed a significant annual increment of diameter - $12.03 \mathrm{~mm}$, while the increment of downy birch in the same year decreased $-7.13 \mathrm{~mm}$. In the stands with the dominant tree species -downy birch, it is advisable to avoid too intense drainage,otherwise the increments of downy birch will decrease.

\section{Actual annual increment of growing stock}

In both PL (Vaccinosa mel. and Myrtillosa mel.) it was observed that the actual annual increment of silver birch is greater than downy birch. In the second PL (Fig. 3) in the whole time period the average wood stock increment of silver birch was $4.8 \mathrm{~m}^{3}$ per ha-1, while the average wood stock increment of downy birch $-2.1 \mathrm{~m}^{3} \mathrm{ha}^{-1}$ which is approximately two times less than wood stock increment of silver birch.

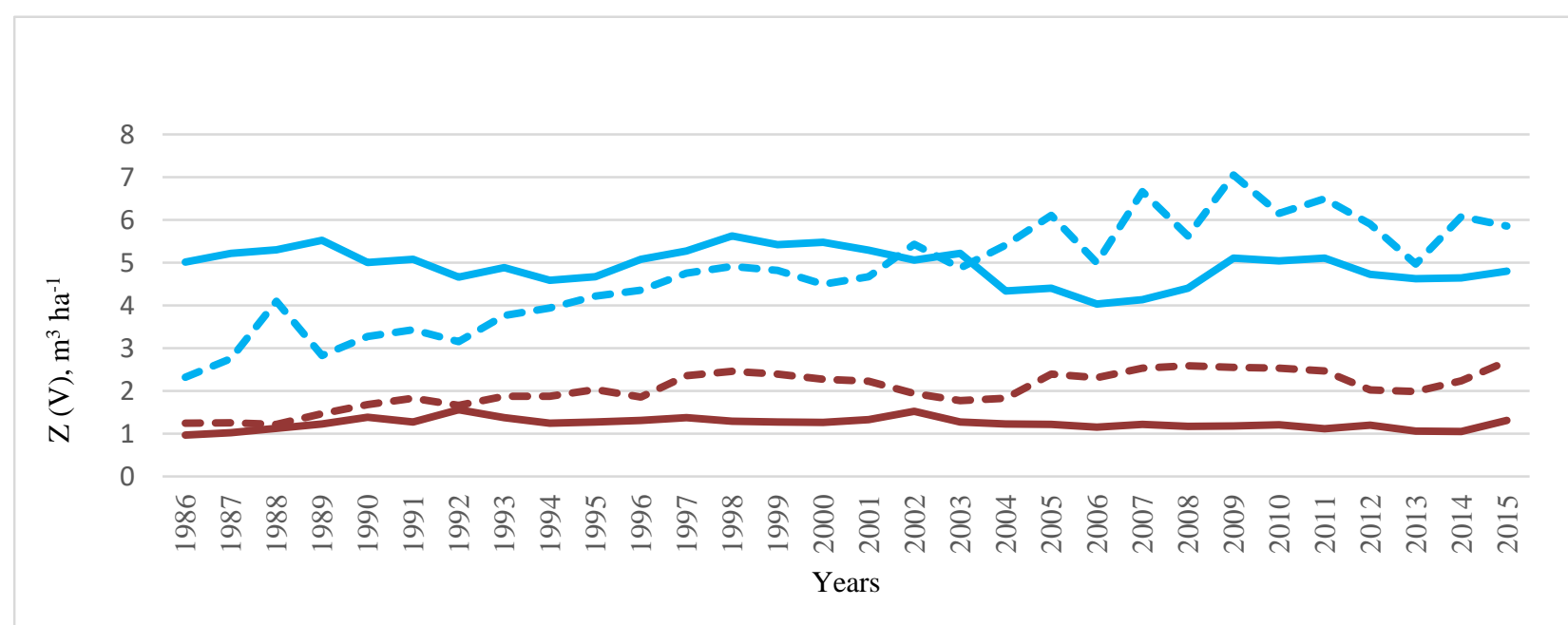

Silver birch_1 plot $\quad$ Downy birch_1 plot $\quad-\infty$ Silver birch_2 plot $\quad-$ - Downy birch_2 plot

Figure 3. Comparison of the dynamics of annual increment of growing stock of silver and downy birch.

The difference between the average increments of both birch species in II PL during the time period under consideration is in average $2.3 \mathrm{~m}^{3} \mathrm{ha}^{-1}$. It can be explained by various factors: the admixture of silver birch is significantly 
larger than admixture in the whole time period and the most important component of the wood stock is diameter. Its annual increment in both PL is greater for downy birch.

\section{CONCLUSIONS AND DISCUSSION}

The most extensive studies regarding the birch growing have been conducted in Northern countries. According to the tables developed in Finland (Koivisto, 1959) total wood stock in naturally regenerated, unmanaged pure stands, more than 80 years old, varies from 320 to $540 \mathrm{~m}^{3} \mathrm{ha}^{-1}$ depending on the location, and it corresponds to the average annual increment from 4.0 to $6.8 \mathrm{~m}^{3} \mathrm{ha}^{-1}$. Respectively, the total wood stock in managed silver birch plantations up to 60-year-old varies from 360 to $560 \mathrm{~m}^{3} \mathrm{ha}^{-1}$ (6.0 and $9.3 \mathrm{~m}^{3} \mathrm{ha}^{-1}$, respectively) (Oikarinen, 1983). In Sweden, the average annual increment in places, favourable for birch, is approximately $10 \mathrm{~m}^{3} \mathrm{ha}^{-1}$ in rotation period from 30 to 60 years (Dahlberg et al., 2006).

According to tables developed by Schwappach (1903) in Central Europe silver birch reaches its total wood stock of $389 \mathrm{~m}^{3}$ per ha at the age of 80 if growing in favourable conditions (Hynynen et al., 2009). As observed by Eriksson, in the poorest locations the increment of growth remains comparatively low, by reaching only $6 \mathrm{~m}$ during a 30 -year period (Eriksson et al., 1997). Studies conducted by Finnish scientists proved that in pure stands silver birch reaches its peak point of height increment at the age of 10 to 20, while that of stock increment - 5 years later (Raulo, 1977; Oikarinen, 1983), rapid increments continue up to 40 to 50 years (Koivisto, 1959; Fries, 1964; Oikarinen, 1983). The dominating height in a birch stand at the age of 50 may be up to $30 \mathrm{~m}$ (Oikarinen, 1983), after which tree growing starts to slow down and before the age of 100 , vitality of birch reduces. Than trees become more responsive to bursting and various risk factors (Hynynen et al., 2009).

Li et al., (2005) have come to conclusion that increments of silver birch is influenced by low air temperature, short day (12-photoperiod), and due to the influence caused by these factors the dormant season of the tree begins (Hynynen et al., 2009). Due to the fact that birch is a pioneer species, it cannot grow in darkened locations for longer periods of time which disrupt the growth process. During a 30-year period, growing in an appropriate location, birch can reach a height up to 24 to $25 \mathrm{~m}$ (Eriksson et al., 1997). Trees maintain vitality and rapid growth occurs when the gaps between dominant trees are relatively wide. According to models designed by Hynynen et al., (1993) silver birch can reach the maximum average trunk diameter of $25 \mathrm{~cm}$, if in the stand grow approximately 600 trees per ha. Birch canopies in dense stands are significantly shorter than in the open field. As the density of plantation increases, the diameter decreases before growing, resulting in a very thin trunk form (Hynynen et al. 2009).

During the last 30 years, in both Vaccinosa mel. and Myrtillosa mel. systematic reduction of height and annual increment of diameter of silver and downy birch species was identified.

In the case of the annual increment of height in Vaccinosa mel. and Myrtillosa mel. and in the case of the annual increment of diameter in Vaccinosa mel. there were observed periods of time when the increments of downy birch slightly exceeded the increments of silver birch.

Downy birch is more productive growing in more humid soils. In periods with more intense rainfalls, increments of downy birch increased to such extent, that out performed the increment volumes of silver birch.

In Vaccinosa mel. and Myrtillosa mel. forest ecosystems silver birch has greater wood stock productivity per ha.

\section{REFERENCES}

1. Dahlberg, A., Egnell, G., Bergh, J, Rytter, L., Westling, O. 2006. Miljöeffekter avskogsbränsleuttag och askåterföring i Sverige En syntes av Energimyndighetens forskningsprogram 1997 till 2004, Rapport ER2006:44, Eskilstuna, Sweden Energimyndigheten [In Swedish].

2. Eriksson H., Johansson U., Kiviste A. 1997. A site-index model for pure and mixed stands of Betula pendula and Betula pubescens in Sweden. Scandinavian Journal of Forestry Research, Vol. 12, Iss. 2, pp. 149-156. https://doi.org/10.1080/02827589709355396

3. Fries, J. 1964. Yield of Betula verrucosa Ehrh. in Middle Sweden and southern North Sweden, Stud. For. Suec. 14, pp.1-303 (in Swedish with English summary).

4. Hynynen, J. 1993. Self-thinning models for even-aged stands of Pinus sylvestris, Picea abies and Betula pendula. Scandinavian Journal of Forestry Research, Vol. 8, Iss. 1-4, pp. 326-336. https://doi.org/10.1080/02827589309382781

5. Hynynen, J., Niemistö, P., Viherä-aarnio, A., Brunner, A., Hein, S., Velling, P. 2009. Silviculture of birch (Betula pendula Roth and Betula pubescens Ehrh.) in northern Europe. An International Journal of Forest Research, Vol. 83, Iss. 1, pp.103-119.

6. Jonsell, B. 2000. Flora Nordica. Lycopodiaceae to Polygonaceae, Vol. 1, The Bergius Foundation, the Royal Swedish Academy of Sciences, Stockholm, Sweden.

7. Koivisto, P. 1959. Growth and yield tables, Commun. Inst. For. Fenn. 51, pp.1-49 [In Finnish with English summary].

8. Li, C., Welling, A., Puhakainen, T., Viherä-Aarnio, A., Ernstsen, A., Junttila, O., Heino, P., Palva, E. 2005. Differential responses of silver birch (Betula pendula) ecotypes to short-day photoperiod and low temperature. Tree Physiology, Vol. 25, Iss. 12, pp.1563-1569. https://doi.org/10.1093/treephys/25.12.1563

9. Liepa, I. 1996. Increment Study. Jelgava, Latvia University of Agriculture [In Latvian].

10. Liepa, I. 2003. An increase. In: Forest encyclopaedia. Vol. 1, Zelta Grauds, Riga [In Latvian].

11. Liepa, I. 2011. Comparison of the accuracy of four boring method for assessing current volume incerement of forest stands. Forest Science, Vol. 23, Iss. 56, pp. 58-70 [In Latvian]. 
12. Liepa, I., Miezīte, O., Bērzina, D., Indriksons, A., Sisenis, L. 2016. Comparison on the dendrometric properties of silver birch Betula pendula Roth and downy birch B.pubescens Ehrh. growing in the similar conditions. Proceedings of VII International Scientific Agriculture Symposium „, Agrosym 2016”, pp. 2874-2878, Jahorina, Bosnia and Herzegovina.

13. Liepiņš, K. 2011. Growth of silver birch (Betula pendula Roth.) in plantations on farmlands in Latvia. Forest Science, Vol. 23, Iss. 56, pp. 3-14.

14. Liepiņš, K., Daugaviete, M., Zālītis, P. 2013. Birch plantations on agricultural lands. Available at http://www.silava.lv/userfiles/file/ERAF\%20LiepinsK/2013_11_20_Gr\%C4\%81mata_ISBN_2.pdf (Accessed on 03/11/2017).

15. Lundgren, L. N., Pan, H., Theander, O., Eriksson, H., Johansson, U., Svenningsson, M. 1995. Developmentof a new chemical method for distinguishing between Betula pendula and Betula pubescens in Sweden. Canadian Journal of Forest Research, Vol. 25, Iss. 7, pp. 1097-1102.https://doi.org/10.1139/x95-121

16. Mauriņš, A., Zvirgzds A. 2009. Betula L. - birch - Betulaceae. In: Dendrologija. University of Latvia, SIA Latgales druka, Riga [In Latvian].

17. Mikola, P. 1985. The Effect of Tree Species on the Biological Properties of Forest Soil. Rapport 3017, Natursvårdsverket, Statens naturvårdverk Solna, Sweden [In Swedish].

18. Niemistö, P. 2013. Effect of growing density on biomass and stem volume growth of downy birch stands on peatland in Western and Northern Finland. Available at https://silvafennica.fi/article/1002 (Assecced on 03/11/2017).

19. Oikarinen, M. 1983. Growth and yield models for silver birch (Betula pendula) plantations in southern Finland. Commun. Inst. For. Fenn, No. 113, pp. 1-75 [In Finnish with English summary].

20. Raulo, J., Koski, V. 1977. Growth of Betula pendula Roth progenies in southern and central Finland. Commun. Inst. For. Fenn. No. 90, pp.1-39 [In Finnish with English summary].

21. Schwappach, A. 1903. Beiträge zur Kenntnis der Wuchsleistung von Birkenbeständen, Zeitschr. f. Forst-u. Jagdwesen [In German].

22. Zalitis, T. 2008. The factors influencing the growth and stem quality of silver birch stands on fertile site types in Latvia. Resume of the PhD paper for the scientific degree of Dr. silv. Silava, Salaspils, Latvian State Forestry Research Inst.

23. Zviedre, A. 1998. Birch. Et cetera, Riga [In Latvian].

24. Zviedre, A., Mangalis I. 2003. Birch. In: Forest encyclopaedia. Vol. 1, Zelta Grauds, Riga [In Latvian]. 